\title{
ODOS MELANOMA. DIAGNOSTIKA IR GYDYMAS
}

\author{
Marius Rinkevičius \\ Lietuvos sveikatos moksly universitetas, Medicinos akademija, Medicinos fakultetas
}

Raktažodžiai: oda, odos melanoma, vėžiniai odos susirgimai, diagnostika.

\section{Santrauka}

Odos melanoma yra viena iš labiausiai paplitusių ligų, sukeliančių didelị mirtingumą. Jos atsiradimas priklauso nuo žmonių rasès, lyties bei amžiaus. Ankstyvas melanomos nustatymas gali sumažinti susirgimo riziką ir išvengti didelio mirtingumo, todèl svarbu analizuoti odos melanomos diagnostikos ir gydymo naujoves. Tyrimo tikslas - remiantis naujausiomis mokslinèmis publikacijomis, apžvelgti odos melanomą, jos diagnostiką ir gydymą. Atlikta 21 mokslinès publikacijos apžvalga. Straipsniai atrinkti naudojantis PubMed, UpToDate ir ScienceDirect duomenų bazėmis. I̦ apžvalgą įtrauktos ne senesnès nei dešimties metų publikacijos anglų kalba.

\section{Ivadas}

Odos melanoma yra viena iš labiausiai paplitusių ligų, sukeliančių didelị mirtingumą. Jos atsiradimas priklauso nuo žmonių rasès, lyties bei amžiaus. Ankstyvas melanomos nustatymas gali sumažinti susirgimo riziką ir mirtingumą [15]. Odos melanoma susijusi su odos segmentais. Nustatę melanomos stadiją, gydytojai gali planuoti tinkamiausią gydymą ligos progresavimui sumažinti $[4,5,21]$. Paprastai melanomos diagnostikos praktika apima vizualinį ištyrimą ir vizualinị (skaičiavimo) ịvertinimą, kuri atlieka dermatologas. Dauguma dermatologų tiria ịtartinas odos vietas, naudodamiesi $\mathrm{ABCD}$ (asimetrijos, kraštinès, spalvos ir skersmens) diagnostikos kriterijais [13]. Vizualiai patvirtinus odos vėži, pasitelkiama skaitmeninė dermatoskopija tolesniam ištyrimui ir apibrèžiamas gydymo planavimo procesas. Skaitmeniniai dermatoskopiniai vaizdai paprastai yra spalvoti RGB (raudona, žalia, mèlyna) vaizdai, plačiai taikomi automatiniam odos ligos aptikimui, ribų ekstrahavimui ir odos véžio tyrimui $[1,16,14]$.

Tyrimo tikslas - remiantis naujausiomis mokslinėmis publikacijomis, apžvelgti odos melanomą, jos diagnostiką ir gydymą.

\section{Tyrimo medžiaga ir metodai}

Atlikta 21 mokslinès publikacijos apžvalga. Straipsniai atrinkti naudojantis PubMed, UpToDate ir ScienceDirect duomenų bazèmis. I apžvalgą įtrauktos ne senesnès nei dešimties metų publikacijos anglų kalba.

\section{Tyrimo rezultatai}

Odos melanoma. Melanoma yra reta, bet žmonèms agresyvi odos vėžio rūšis [11]. Daugeliu atvejų sklaidos etape liga atspari gydymui citostatikais ir radioterapija, todèl su melanogenezès procesu ir naviko progresavimu susijusių naujų molekulinių mechanizmų identifikavimas leidžia sukurti tikslinę terapiją, darančią pastebimą poveiki [11]. Melanogenezès pagrindas yra genetinių sutrikimų kaupimasis melanocituose (dažniausios yra šios mutacijos: B-Raf proto onkogenas, serino/treonino kinazè, N-Ras proto onkogenas, GTPaze ir fosfatazè bei tenzino homologas). Mikroaplinkos elementų ir melanocitu genetinių pokyčių sąveikoje displazinis melanocitas virsta melanomos ląstele, o tolesniuose etapuose atsiranda vietinè pirminio pažeidimo invazija ir sklaida [11].

Melanomos mikroaplinka yra labai nevienalytè ląstelių populiacija, apimanti fibroblastus, makrofagus, limfocitus, kitas imuninès sistemos ląsteles, adipocitus ir tas ląsteles, kurios, prasiskverbusios ị tarpaląstelinę matricą, sudaro odos kraujagyslių struktūrinius elementus [19]. Tai aktyvina baltymų medžiagas, ịskaitant sekrecinius baltymus (pvz., metaloproteinazes ar osteonektiną) ir augimo faktorius, pvz., transformuojantis augimo faktorius- $\beta$ (TGF- $\beta$ ), epidermio augimo faktorius (EGF), hepatocitų augimo faktorius ir trombocitų augimo faktorius $[19,10]$, o šie pokyčiai sukelia ląstelèse hipoksiją [3].

Iprastai melanoma apibūdinama kaip tipiška genetinè liga, susijusi su kaupiamaisiais epigenetiniais ir mutaciniais pokyčiais, sukeliančiais negrịžtamas ląstelių metastazes, diferenciaciją ir proliferaciją [18].

Odos melanomos diagnostika. Viena iš diagnostikos priemonių îvertinti pirminès odos melanomos išplitimą, yra sarginių limfmazgių biopsija. Norint taikyti šią procedūrą, 
melanoma turi atitikti keletą kriterijų. Biopsija atliekama tada, kai kliniškai nenustatytas išplitimas ị sritinius limfmazgius, nediagnozuotos satelitinès, tranzitinès ar tolimosios metastazès. Svarbus ir melanomos storis. Melanomos Breslow rodikliui esant $\leq 0,75 \mathrm{~mm}$, biopsija neindikuotina dèl labai mažos naviko metastazavimo rizikos. Esant 0,76-1 mm, biopsija gali būti atliekama, kai yra papildomų blogos prognozès veiksnių; melanomos storiui esant $\geq 1 \mathrm{~mm}$, sarginio limfmazgio biopsija rekomenduojama, jei neprieštarauja anksčiau išvardytoms sąlygoms [17].

Tradiciškai norint nustatyti melanoma sergančių pacientų slaptą metastazavusią ligą, atliekami pagrindiniai radiologiniai tyrimai, tokie kaip krūtinès ląstos rentgenograma. Dèl ribotų dvimačių minkštujų audinių vaizdų rentgenogramos tikslumas nustatyti tikrąsias metastazes plaučiuose, palyginti su klaidingais ir klaidingai neigiamais rezultatais, yra ribotas [20], todèl dabartinejje klinikinëje praktikoje rentgeno tyrimas melanomos stebejimui naudojamas retai [9].

Ultragarsinis vaizdavimas dažnai naudojamas regioninių limfmazgių būklei vertinti. Nors ultragarso jautrumas priklauso nuo echoskopuotojo kompetencijos [2, 12], irodyta, kad limfmazgių stebejjimui ultragarsas turi didžiausią jautrumą ir specifiškumą, atitinkamai 96 ir 99 procentus [2]. Pacientams, sergantiems I ir II stadijos melanoma, regioninio limfmazgių baseino stebejjimas ultragarsu yra pranašesnis už klinikinį tyrimą (limfmazgių baseino palpacija) [12], todèl reikia apsvarstyti stebejjimą ultragarsu, kad būtų galima stebeti pacientus, kuriems atlikta teigiama kontrolinė limfmazgių biopsija ir kuriems neatliekamas skubus limfmazgių ištyrimas [8]. Ultragarso stebejjimas turètų būti rekomenduojamas pacientams, kuriems nerekomenduojama arba jie nenori atlikti kontrolinès limfmazgių biopsijos, tačiau dèl nepalankių pirminių naviko savybių išlieka didelẻ ligos progresavimo rizika [9].

Informacija, gauta iš pirminès odos piktybinès melanomos histopatologinio preparato ir aprašyta dermatopatologo išvadoje kartu su klinikiniais duomenimis, suteikia neįkainojamą prognostinę reikšmę kitų sričių gydytojams, pasirenkantiems gydymo taktiką bei prognozuojantiems pacientų išgyvenamumą.

Odos melanomos gydymas. Analizuojant odos melonomos gydymą, pastebètas tarptautinių gairių nenuoseklumas dèl stebėjimo vaizdo naudojimo. Dabartinès gairès daugiausia grindžiamos ekspertų sutarimu, o ne patikimais ịrodymais. Nacionalinis išsamus vėžio tinklas pacientams, sergantiems IIB-IV stadijos besimptome melanoma, rekomenduoja atlikti kompiuterinès tomografijos arba pozitronų emisijos tomografijos nuskaitymą kas 3-12 mènesių [6]. Europos medicinos onkologų draugija rekomenduoja tik fizinį patikrinimą kas tris mènesius [7].

\section{Išvados}

1. Odos melanoma - tai véžinis odos susirgimas, susijęs su kaupiamaisiais epigenetiniais ir mutaciniais pokyčiais, sukeliančiais nepataisomas ląstelių metastazes, diferenciaciją ir proliferaciją.

2. Odos melanomos diagnostika atliekama remiantis sarginių limfmazgių biopsija bei ultragarsiniais tyrimais. Dėl odos melanomos rekomenduojama tikrintis mažiausiai kas tris mènesius.

3. Odos melanomai gydyti dažniausiai taikomi chirurginiai ar lazeriniai būdai. Pastebėtas tarptautinių gairių nenuoseklumas dèl stebejjimo vaizdo naudojimo.

\section{Literatūra}

1. Barata C, Celebi ME, Marques JS. Improving dermoscopy image classification using color constancy. IEEE J Biomed Health Inform 2015;19:1146-1152.

https://doi.org/10.1109/ICIP.2014.7025716

2. Bafounta M, Beauchet A, Chagnon S, Saiag P. Ultrasonography or palpation for detection of melanoma nodal invasion: a metaanalysis. Lancet Oncol 2004;5(11):673-80.

https://doi.org/10.1016/S1470-2045(04)01609-2

3. Bedogni B, Powell MB. Hypoxia, melanocytes and melanoma-survival and tumor development in the permissive microenvironment of the skin. Pigment Cell Melanoma Res 2009;22:166-174

https://doi.org/10.1111/j.1755-148X.2009.00553.x

4. Celebi ME, Zornberg A. Automated quantification of clinically significant colors in dermoscopy images and its application to skin lesion classification. IEEE Syst J 2014;8: 980-984.

https://doi.org/10.1109/JSYST.2014.2313671

5. Celebi ME, Iyatomi H, Schaefer G, Stoecker WV. Lesion border detection in dermoscopy images. Comput Med Imag Graph 2009;33:148-153

https://doi.org/10.1016/j.compmedimag.2008.11.002

6. Coit D, Andtbacka R, Bichakjian C, Dilawari R, Dimaio D, Guild V, et al. Melanoma. J Natl Compr Canc Netw 2009;7(3):250-75. https://doi.org/10.6004/jnccn.2009.0020

7. Dummer R, Hauschild A, Pentheroudakis G. Cutaneous malignant melanoma: ESMO Clinical Recommendations for diagnosis, treatment and follow-up. Ann Oncol 2009;20 S4:iv129-31.

https://doi.org/10.1093/annonc/mdp152

8. Faries M, Thompson J, Cochran A, Andtbacka R, Mozzillo $\mathrm{N}$, Zager J, et al. Completion Dissection or Observation for Sentinel-Node Metastasis in Melanoma. N Engl J Med 2017;376(23):2211-22.

https://doi.org/10.1056/NEJMoa1613210

9. Howard MD. Melanoma Radiological Surveillance: A Review of Current Evidence and Clinical Challenges. 2020; 93(1): 207-213 
10. Kalluri R, Weinberg RA. The basics of epithelial-mesenchymal transition. J Clin Invest 2009;119:1420-1428. https://doi.org/10.1172/JCI39104

11. Lin K, Baritaki S, Militello L, Malaponte G, Bevelacqua Y, Bonavida B. The role of B-RAF mutations in melanoma and

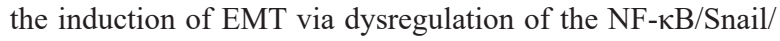
RKIP/PTEN circuit. Genes Cancer 2010;1:409-420. https://doi.org/10.1177/1947601910373795

12. Machet L, Nemeth-Normand F, Giraudeau B, Perrinaud A, Tiguemounine J, Ayoub J, et al. Is ultrasound lymph node examination superior to clinical examination in melanoma follow-up? A monocentre cohort study of 373 patients. Br J Dermatol 2005;152(1):66-70. https://doi.org/10.1111/j.1365-2133.2004.06262.x

13. Nachbar F, Stolz W, Merckle T, Cognetta AB, Vogt T, et al. The ABCD rule of dermatoscopy: High prospective value in the diagnosis of doubtful melanocytic skin lesions. J Am Acad Dermatol. 1994;30:551-559. https://doi.org/10.1016/S0190-9622(94)70061-3

14. Nilanjan D, Venkatesan R, Amira SA, João Manuel RS. Tavares Social Group Optimization Supported Segmentation and Evaluation of Skin Melanoma Images. 2018.

15. Premaladha J, Sujitha S, Priya ML, Rajichandran KS. A survey on melanoma diagnosis using image processing and soft computing techniques. Res J Inf Tech 2014;6:65-80. https://doi.org/10.3923/rjit.2014.65.80

16. Rajinikanth V, Madhavaraja N, Satapathy SC, Fernandes SL. Otsu's multi-thresholding and active contour snake model to segment dermoscopy images. J Med Imag Health Inf 2017; 7(8):1837-1840. https://doi.org/10.1166/jmihi.2017.2265

17. Samalavičius N, Aleknavičius E, Pleckienė A. Odos melanomos diagnostika ir gydymas. Vilnius, SAM; 2014.

18. Schadendorf D, van Akkooi ACJ, Berking C, Griewank KG, Gutzmer R, Hauschild A, Stang A, Roesch A, Ugurel S. Melanoma. Lancet 2018;392(10151):971-984.

https://doi.org/10.1016/S0140-6736(18)31559-9
19. Taylor MA, Parvani JG, Schiemann WP. The pathophysiology of epithelial-mesenchymal transition induced by transforming growth factor-beta in normal and malignant mammary epithelial cells. J Mammary Gland Biol Neoplasia 2010;15:169-190. https://doi.org/10.1007/s10911-010-9181-1

20. Terhune M, Swanson N, Johnson T. Use of chest radiography in the initial evaluation of patients with localized melanoma. Arch Dermatol 1998;134(5):569-72.

https://doi.org/10.1001/archderm.134.5.569

21. Amelard R, Glaister J, Wong A, Clausi DA. Melanoma decision support using lighting-corrected intuitive feature models. Comput Vis Tech Diagn Skin Cancer 2013,193-219. https://doi.org/10.1007/978-3-642-39608-3_7

\section{SKIN MELANOMA. DIAGNOSIS AND TREATMENT M. Rinkevičius}

Keywords: skin, skin melanoma, skin cancers, diagnosis. Summary

Skin melanoma is one of the most common diseases, affecting people's race, gender and age, and causing high mortality. premature detection of melanoma can reduce the risk of developing the disease and prevent high mortality rates. therefore, it is very important to analyze the diagnosis and treatment of skin melamoma. the aim of the study is to review skin melanoma and its diagnosis and treatment based on the latest scientific publications.

A scientific review of 21 publications was performed. Articles were selected using PubMed, UpToDate, and ScienceDirect databases. The review includes publications in English not older than ten years.

Correspondence to: mariusdvynys@gmail.com

Gauta 2021-09-06 